\title{
The E3 ubiquitin ligase Cbl-b inhibits tumor growth in multidrug-resistant gastric and breast cancer cells
}

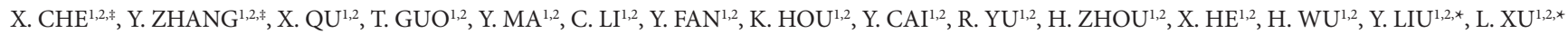 \\ ${ }^{1}$ Department of Medical Oncology, the First Hospital of China Medical University, Shenyang 110001, China; ${ }^{2}$ Key Laboratory of Anticancer Drugs \\ and Biotherapy of Liaoning Province, the First Hospital of China Medical University, Shenyang 110001, China
}

*Correspondence: cmuxuling@163.com, cmuliuyunpeng@hotmail.com

${ }^{*}$ Contributed equally to this work.

Received February 10, 2017 / Accepted April 10, 2017

\begin{abstract}
Most receptor tyrosine kinases (RTKs) contribute to tumor growth, and their ubiquitination and degradation is related to the inhibition of tumor growth. Our previous study showed that the ubiquitin ligase Cbl-b was expressed at low levels in multidrug-resistant (MDR) gastric cancer cells compared with their parental cells. However, whether enhancement of Cbl-b expression in MDR cancer cells could prevent tumor proliferation via ubiquitination and degradation of RTK remains unclear. In the present study, Cbl-b overexpression reduced cell proliferation in MDR gastric and breast cancer cells, and effectively inhibited tumor growth in vivo. Additionally, Cbl-b overexpression reduced the total protein level of insulin-like growth factor 1 (IGF-1R), an important member of the RTK family. Moreover, Cbl-b overexpression promoted interaction of Cbl-b with IGF-1R, and induced ubiquitination and degradation of IGF-1R and inactivation of the IGF-1R pathway. These results suggest that the ubiquitin ligase Cbl-b inhibited tumor growth via ubiquitination and degradation of IGF-1R in MDR gastric and breast cancer cells.
\end{abstract}

Key words: Cbl-b, IGF-1R, MDR, proliferation

One important characteristic of cancer cells is their ability to express growth factors and growth factor receptors, which contribute to tumor progression $[1,2]$. Strict regulation of signaling by receptor tyrosine kinases (RTKs) is necessary for biological processes, and its disruption can result in tumor progression [3-5]. Overexpression of RTKs has been reported in some cancer types, such as gastric, breast and prostate cancers. Therefore, promotion of RTK ubiquitination and degradation represents a new approach for inhibiting tumor growth $[6,7]$. Several studies have reported that casitas Blineage lymphoma (CBL) family members play a vital role in the downregulation of RTK via their E3 ubiquitin ligase activity $[8,9]$. Moreover, the inhibition of c-Cbl function by c-Cbl mutations has been shown to increase non-small cell lung cancer cell proliferation [10], which indicates that c-Cbl may function as a negative regulator of cancer proliferation. Our previous study showed that the CBL family member Cbl-b is expressed at low levels in multidrug resistant (MDR) gastric cancer cells compared with their parental cells [11]. Furthermore, Cbl-b overexpression reversed multidrug resist- ance via downregulation of P-glycoprotein (P-gp) expression [11]. However, whether Cbl-b inhibits tumor proliferation in MDR cancer cells remains unclear.

Previous studies reported that the ubiquitin ligase Cbl-b plays an important role in inactivating the phosphatidylinositol 3-kinase (PI3K)/protein kinase B (Akt) and Raf/ mitogen-activated protein kinase (MAPK)/extracellular signal-regulated kinase (ERK) pathways [12-15]. Furthermore, we previously demonstrated that Cbl-b overexpression reversed multidrug resistance by suppressing Akt activation [11]. Insulin-like growth factor receptor (IGF-IR) is an upstream regulatory molecule of Akt and ERK. A recent study reported that IGF-IR was highly expressed in MDR colorectal cells, and that silencing IGF-IR decreased proliferation of MDR cells [16]. Additionally, after IGF-1 stimulation, c-Cbl associated with IGF-IR and mediated receptor polyubiquitination [17]. Moreover, we recently showed that Cbl-b reversed cell migration induced by IGF-I in gastric cancer cells by targeting IGF-IR for degradation [18]. We therefore considered the possibility that Cbl-b could inhibit tumor proliferation 
via ubiquitination and degradation of IGF-IR in MDR cancer cells to be worthy of further investigation.

In the present study, we demonstrated that Cbl-b overexpression reduced cell proliferation in MDR gastric and breast cancer cells, and effectively inhibited tumor growth in vivo. Cbl-b prevented tumor proliferation via ubiquitination and degradation of IGF-IR and consequent inactivation of IGFIR pathway.

\section{Materials and methods}

Cell culture. The human gastric adenocarcinoma SGC7901 cells and the human breast carcinoma MCF-7 cells were purchased from the Academy of Military Medical Science (Beijing, China). The adriamycin-resistant variant of SGC7901 (SGC7901/Adr) was kindly provided by the Fourth Military Medical University (Xi' an, China). The adriamycin-resistant variant of MCF-7 (MCF-7/Adr) was established by selecting for resistant colonies by culturing the parent cell line in $1 \mu \mathrm{g} /$ $\mathrm{ml}$ adriamycin.

Transfections of Cbl-b WT constructs. Transfections of Cbl-b WT constructs were performed as described previously $[11,19]$. SGC7901/Adr and MCF-7/Adr cells were seeded at $4 \times 10^{5}$ cells/well in six-well plates overnight, then the cells

A
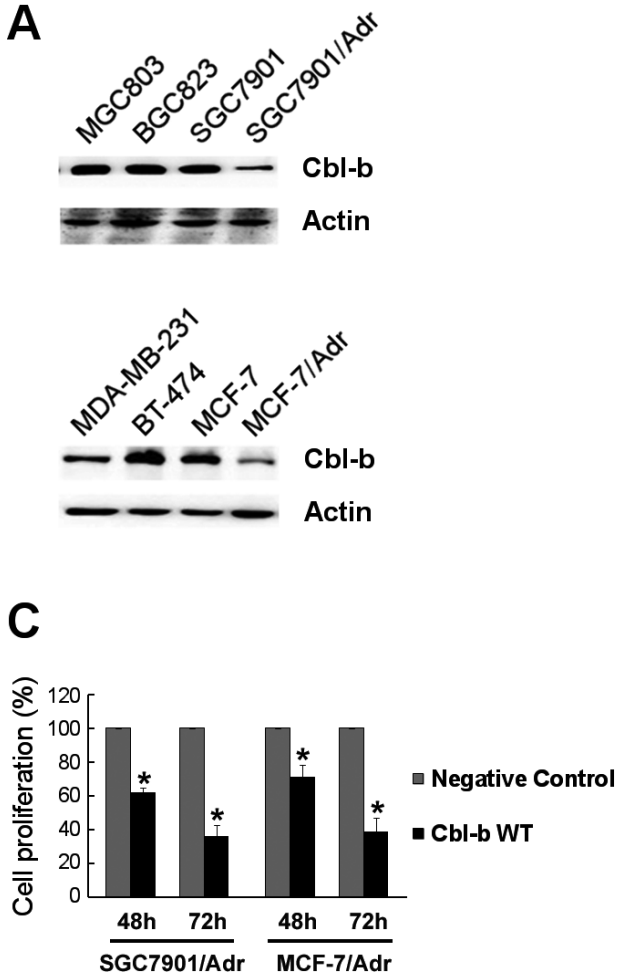

were transfected by lipofectamine 2000 reagent with pcDNA 3.1 plasmid including full-length Cbl-b. pcDNA 3.1 vector served as the negative control. After transient transfections for $48 \mathrm{~h}$, Cbl-b expression was evaluated by western blot.

Western blot and immunoprecipitation. SGC7901/Adr and MCF-7/Adr cells were rinsed twice with phosphatebuffered saline and lysed in $1 \%$ Triton lysis buffer on ice. For immunoprecipitation, cell lysates were mixed with the indicated primary antibody and protein A-sepharose beads at $4{ }^{\circ} \mathrm{C}$ overnight. The immunoprecipitated proteins were eluted by heat treatment at $100^{\circ} \mathrm{C}$ for 5 min with $2 \mathrm{X}$ sampling buffer. Total cell proteins were separated by sodium dodecyl sulfate-polyacrylamide gel electrophoresis. The membranes were blocked with $5 \%$ skimmed milk in Tris-buffered saline Tween-20 (TBST) buffer overnight. Various primary antibodies were: Cbl-b, p-ERK, ERK (Santa Cruz, USA); p-IGF-1R, IGF-1R, p-Akt, Akt, (Cell Signaling Technology, USA). Then, the membrane was incubated with the secondary antibodies at room temperature. Finally, proteins on the membranes were visualized by an enhanced chemiluminescence reagent in the Electrophoresis Gel Imaging analysis system (DNR Bio-Imaging Systems, Israel).

MTT assay. SGC7901/Adr and MCF-7/Adr cells were seeded at $4 \times 10^{3}$ cells/well in 96 -well plates overnight, then

\section{B}
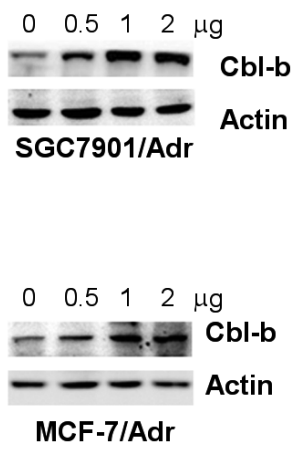

D

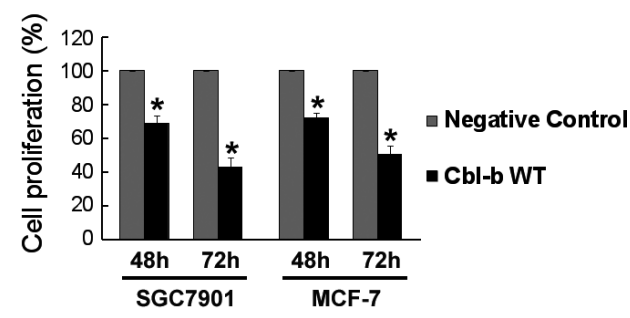

Figure 1. Cbl-b overexpression inhibited cell proliferation in MDR gastric and breast cancer cells. (A) The expression of Cbl-b in gastric and breast cancer cells was detected by western blot. (B) After SGC7901/Adr and MCF-7/Adr cells were transfected with $0.5,1$ and $2 \mu \mathrm{g}$ Cbl-b WT for $48 \mathrm{~h}$, the expression of Cbl-b was detected by western blot. (C) After SGC7901/Adr and MCF-7/Adr cells were transfected with $2 \mu \mathrm{g}$ Cbl-b WT and empty vector plasmid for $48 \mathrm{~h}$, cell viability was analyzed by MTT assay at another $48 \mathrm{~h}$ and $72 \mathrm{~h} .{ }^{*} P<0.05$. (D) After SGC7901 and MCF-7 cells were transfected with $2 \mu \mathrm{g}$ Cbl-b WT and empty vector plasmid for $48 \mathrm{~h}$, cell viability was analyzed by MTT assay at another $48 \mathrm{~h}$ and $72 \mathrm{~h} .{ }^{*} P<0.05$. 
the cells were transiently transfected with $2 \mu \mathrm{g}$ Cbl-b WT for 48 and $72 \mathrm{~h} .25 \mathrm{~mL}$ of MTT solution $(5 \mathrm{mg} / \mathrm{mL})$ was added to each well and the cells were incubated for $4 \mathrm{~h}$ at $37^{\circ} \mathrm{C}$. Then, the cells were lysed in $200 \mathrm{~mL}$ of dimethylsulfoxide. The optical density was measured at $570 \mathrm{~nm}$ with a microplate reader.

Tumor growth in vivo. Female BALB/c nude mice, 4-6 weeks of age, were acquired from the National Laboratory Animal Center (Shanghai, China) after obtaining appropriate institutional review board permission and raised in pathogenfree environment. The transfected SGC7901/Adr $\left(5 \times 10^{6}\right)$ in $100 \mu \mathrm{L}$ were implanted subcutaneously into mice. Tumors were measured with a caliper every 3 days, and tumor volume was calculated using the formula $\mathrm{V}=1 / 2$ ( width $^{2} \times$ length). Mice body weight was measured. Tumors were fixed and stained with hematoxylin and eosin (H\&E) for further pathological confirmation.

Immunohistochemistry. Immunohistochemical staining for Cbl-b was performed using a streptavidin-peroxidase procedure as described previously $[11,19]$. Antibody against Cbl-b was from Santa Cruz Biotechnology (USA). For statistical analysis, immunostaining was considered positive when the tumor mass occupied more than $10 \%$ of the cross-sectional core area and when $10 \%$ or more of the neoplastic cells were stained.
Statistical analysis. All the presented data were expressed as the mean \pm SD and representative results were from three independent experiments. Statistical analysis was carried out using SPSS 18.0 software. Statistical comparisons were calculated by Student' s two-tailed t-test. $P<0.05$ was considered statistically significant.

\section{Results}

Cbl-b overexpression reduced cell proliferation in MDR gastric and breast cancer cells. Cbl-b expression in various gastric and breast cancer cell types was evaluated. Interestingly, SGC7901/Adr and MCF-7/Adr cells showed lower Cbl-b expression than their parental cells and the other cells studied (Figure 1A). Transient transfection with $0.5,1$, or $2 \mu$ g wild-type (WT) Cbl-b increased Cbl-b expression (Figure 1B). Importantly, transient transfection with $2 \mu \mathrm{g}$ WT Cbl-b inhibited cell proliferation at 48 and $72 \mathrm{~h}$ compared with the negative control (Figure 1C). In addition, Cbl-b overexpression also reduced cell proliferation at 48 and $72 \mathrm{~h}$ in non-MDR gastric and breast cancer cells (Figure 1D). These results suggest that Cbl-b overexpression prevented cell proliferation in MDR gastric and breast cancer cells.

Cbl-b overexpression effectively inhibited tumor growth in vivo. WT Cbl-b was transfected into SGC7901/Adr cells,
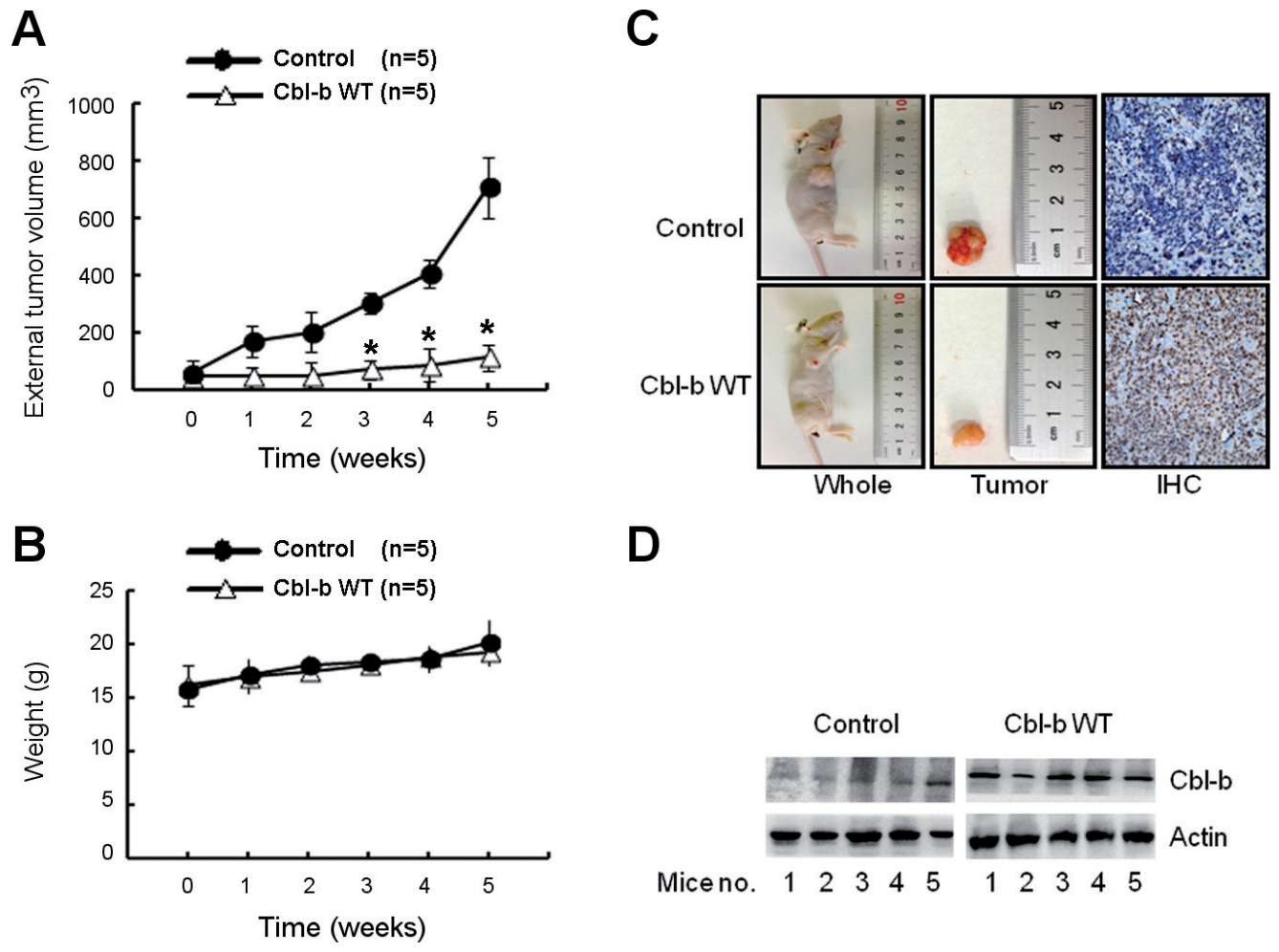

D

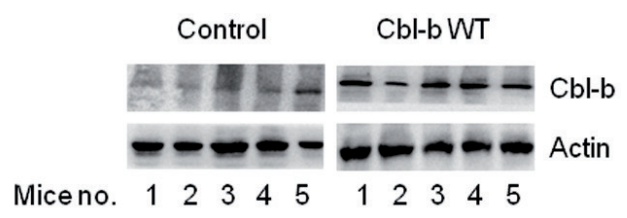

Figure 2. Cbl-b overexpression effectively inhibited tumor growth in vivo. (A) Tumor and (B) body weights of mice injected subcutaneously with SGC7901/ Adr cells transfected with Cbl-b WT or the empty vector (Control). ${ }^{\star} \boldsymbol{P}<0.05$. (C) SGC7901/Adr controls and SGC7901/Adr Cbl-b WT were implanted subcutaneously into the right flanks of 4-6-week-old female nude mice $(n=5)$, and tumor volumes were measured at 35 days after implantation. Cbl-b expression was analyzed in sections from subcutaneous tumors by immunohistochemistry $(20 \times)$. (D) Cbl-b levels in Cbl-b WT group compared with the control group at 35 days in SGC7901/Adr xenografts were detected by western blot. 
which were then implanted subcutaneously into nude mice. Animals injected with SGC7901/Adr xenografts carrying WT Cbl-b showed significantly reduced tumor mass compared with the control group (Figure 2A). However, there was no obvious difference in body weight between the two groups (Figure 2B). We then analyzed Cbl-b expression by immunohistochemistry and western blot in sections from subcutaneous tumors overexpressing Cbl-b (Figure 2C) (Figure 2D); both approaches demonstrated that Cbl-b expression persisted for 35 days after xenograft implantation. These results indicate that $\mathrm{Cbl}-\mathrm{b}$ overexpression reduced tumor growth in vivo.

Cbl-b overexpression promoted ubiquitination and degradation of IGF-1R in MDR gastric and breast cancer cells. To clarify the mechanism of Cbl-b-mediated inhibition
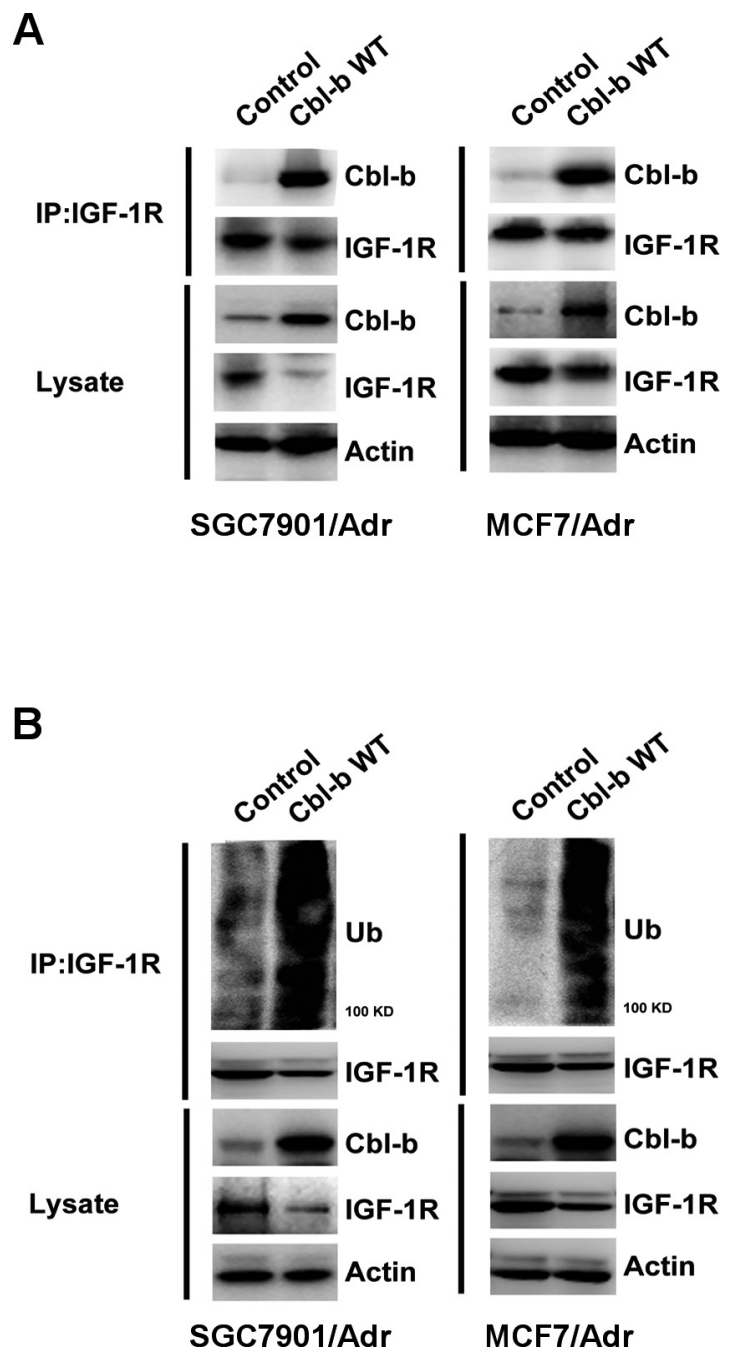

Figure 3. Cbl-b overexpression promoted ubiquitination and degradation of IGF-1R in MDR gastric and breast cancer cells. SGC7901/Adr and MCF7/Adr cells were transfected with Cbl-b WT and empty vector plasmid for $48 \mathrm{~h}$. (A) The interaction of Cbl-b and IGF-1R was detected by immunoprecipitation and western blot. (B) The ubiquitination of IGF-1R was detected by immunoprecipitation and western blot. of tumor growth in MDR gastric and breast cancer cells, WT Cbl-b was transiently transfected into SGC7901/Adr and MCF-7/Adr cells. As shown in Figure 3A, Cbl-b overexpression reduced total IGF-1R protein levels in SGC7901/Adr

A

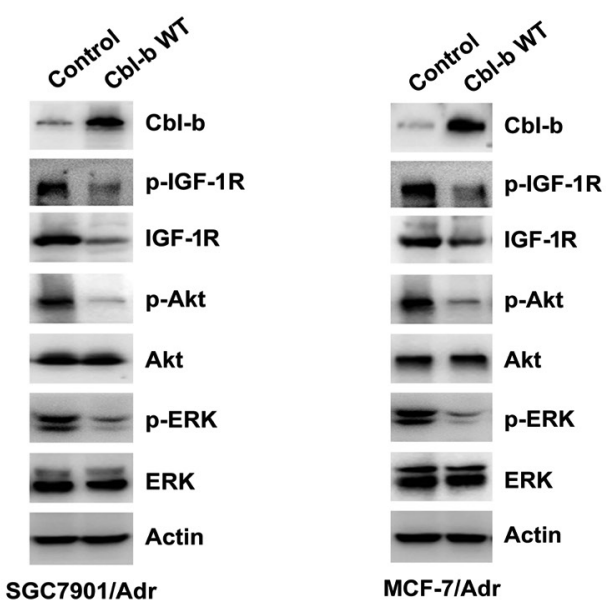

B

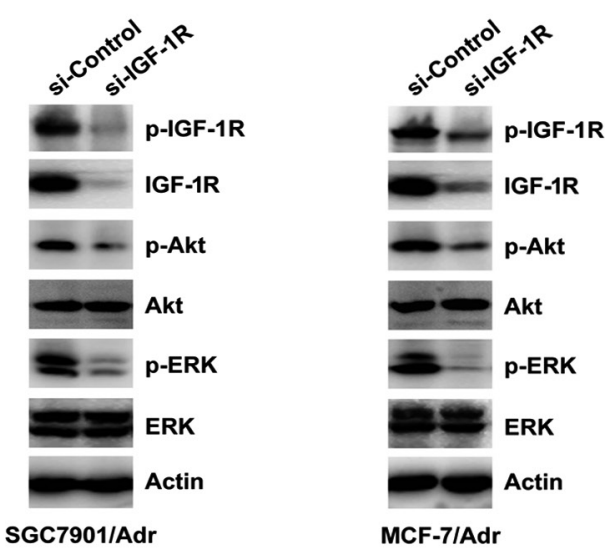

C

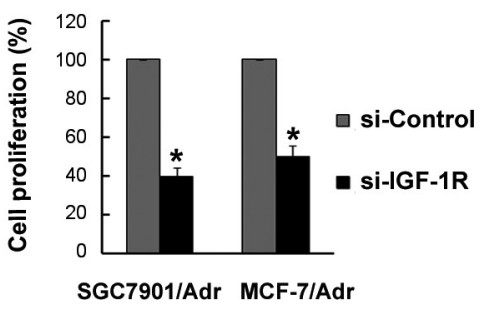

Figure 4. Cbl-b overexpression inhibited activation of the IGF-1R pathway in MDR gastric and breast cancer cells. (A) SGC7901/Adr and MCF-7/ Adr cells were transfected with Cbl-b WT and empty vector plasmid for $48 \mathrm{~h}$. IGF-1R and downstream Akt/ERK were analyzed by western blot. (B) SGC7901/Adr and MCF-7/Adr cells were transfected with si-IGF-1R and negative control plasmid for $48 \mathrm{~h}$. IGF-1R and downstream Akt/ERK were analyzed by western blot. (C) After SGC7901/Adr and MCF-7/Adr cells were transfected with si-IGF-1R and negative control plasmid for $48 \mathrm{~h}$, cell viability was analyzed by MTT assay at another $72 \mathrm{~h} .{ }^{*} P<0.05$. 
and MCF-7/Adr cells. Importantly, WT Cbl-b transfection also promoted the interaction of Cbl-b with IGF-1R (Figure $3 \mathrm{~A}$ ), and further induced IGF-1R ubiquitination and degradation (Figure 3B). These results suggest that Cbl-b inhibited cell proliferation in MDR gastric and breast cancer cells via ubiquitination and degradation of IGF-1R.

Cbl-b overexpression inhibited activation of the IGF-1R pathway in MDR gastric and breast cancer cells. It was previously reported that calycosin prevented cell growth in estrogen receptor-positive breast cancer cells via inhibition of IGF-1R and the MAPK/ERK and PI3K/Akt pathways [20]. Thus, we examined the phosphorylation of IGF-1R and downstream Akt and ERK. Cbl-b overexpression not only reduced IGF$1 \mathrm{R}$ expression, but also inhibited activation of IGF-1R and downstream Akt/ERK in SGC7901/Adr and MCF-7/Adr cells (Figure 4A). To clarify the importance of IGF-1R in MDR cells, we detected the IGF-1R signal pathway and cell proliferation after using si-IGF-1R. The inhibition of IGF-1R expression prevented activation of IGF-1R and Akt/ERK (Figure 4B), and finally inhibited cell proliferation in SGC7901/Adr and MCF-7/Adr cells (Figure 4C). These results suggest that Cbl$\mathrm{b}$ prevented tumor proliferation in MDR gastric and breast cancer cells by inhibiting the IGF-1R pathway.

\section{Discussion}

Many studies have demonstrated that RTKs act as molecular switches to regulate many cellular signals, that their dysregulation contributes to a variety of human malignancies, and that $\mathrm{Cbl}$ family proteins serve as negative regulators for some RTKs. For instance, loss of c-Cbl-dependent negative regulation was shown to be involved in tumorigenesis in breast, lung, prostate cancer cells and myelodysplastic syndrome [21-24]. Additionally, by directly inhibiting c-Cbl and Cbl-b expression, miR-675 increases the stability of EGFR and c-Met, and promotes tumor growth [15], which indicates that $\mathrm{c}-\mathrm{Cbl}$ and Cbl-b may be negative regulators of tumor growth. Our previous study showed that Cbl-b was expressed at low levels in MDR gastric cancer cells compared with their parental cells, whereas there was no difference in c-Cbl expression [11]. In the present study, Cbl-b overexpression prevented proliferation of MDR gastric and breast cancer cells, and effectively inhibited tumor growth in nude mice bearing MDR gastric cancer cells. Further to our previous study, which reported that Cbl-b reversed drug resistance in MDR gastric cancer cells [11], the present study demonstrated that Cbl-b also plays an important role in the inhibition of tumor growth in MDR gastric and breast cancer cells.

Emerging evidence suggests that IGF-1R could drive renal cancer cell proliferation [25]. Furthermore, miR-133a has been shown to prevent cell proliferation in human osteosarcoma cells by inhibiting IGF-1R expression and Akt/ERK signaling activation [26]. IGF-IR was reported to be highly expressed in colorectal MDR cells, and inhibiting IGF-IR expression decreased MDR cell proliferation [16]. Additionally, previous studies including our own have shown that $\mathrm{c}-\mathrm{Cbl}$ and $\mathrm{Cbl}-\mathrm{b}$ promoted the ubiquitination and degradation of IGF-IR in cancer cells $[17,18]$. In the present study, Cbl-b overexpression promoted interaction of Cbl-b with IGF-1R, induced ubiquitination and degradation of IGF-1R, and thereby reduced IGF-1R expression and activation of the IGF-1R pathway in MDR cancer cells. Taken together, these findings indicate that IGF-1R is a key target of Cbl-b in the regulation of tumor proliferation in MDR gastric and breast cancer cells.

In summary, our study demonstrated that the ubiquitin ligase Cbl-b inhibited tumor growth in MDR gastric and breast cancer cells via ubiquitination and degradation of IGF-IR and consequent inactivation of the IGF-IR pathway.

Acknowledgements: This work is supported by the Chinese National Foundation of National Sciences (No. 81673025, 81270036), and the Program for Liaoning Excellent Talents in University (No. LR2014023), and Science and Technology Project of Liaoning Province (No. 2014021069, 2014226033, 2014225013), and National Natural Science Foundation-Outstanding Youth Foundation Training Project of China Medical University (No. YQ20160002). The authors thank Jian Gao and Lu Yao (Experiment Technology Center of China Medical University) for kindly providing technical support.

\section{References}

[1] KOUVIDI K, NIKITOVIC D, BERDIAKI A, TZANAKAKIS GN. Hyaluronan/RHAMM interactions in mesenchymal tumor pathogenesis: role of growth factors. Adv Cancer Res 2014; 123: 319-349. https://doi.org/10.1016/B978-0-12800092-2.00012-5

[2] OVCARICEK T, CUFER T, KERN I, SODJA E, SADIKOV A. Efficacy of tyrosine kinase inhibitors in routine clinical practice: epidermal growth factor mutations and their implications. J Cancer Res Ther 2013; 9: 261-266. https://doi. org/10.4103/0973-1482.113379

[3] SHAW AT, HSU PP, AWAD MM, ENGELMAN JA. Tyrosine kinase gene rearrangements in epithelial malignancies. Nat Rev Cancer 2013; 13: 772-787. https://doi.org/10.1038/ $\underline{\operatorname{nrc} 3612}$

[4] NISHIE K, KAWAGUCHI T, TAMIYA A, MIMORI T, TAKEUCHI $\mathrm{N}$ et al. Epidermal growth factor receptor tyrosine kinase inhibitors beyond progressive disease: a retrospective analysis for Japanese patients with activating EGFR mutations. J Thorac Oncol 2012; 7: 1722-1727. https://doi.org/10.1097/ JTO.0b013e31826913f7

[5] CHEN J. Regulation of tumor initiation and metastatic progression by Eph receptor tyrosine kinases. Adv Cancer Res 2012; 114: 1-20. https://doi.org/10.1016/B978-0-12-386503$\underline{8.00001-6}$

[6] BHOWMICK P, PANCSA R, GUHAROY M, TOMPA P. Functional diversity and structural disorder in the human ubiquitination pathway. PLoS One 2013; 8: e65443. https:// doi.org/10.1371/journal.pone.0065443

[7] SEVERE N, DIEUDONNE FX, MARIE PJ. E3 ubiquitin ligase-mediated regulation of bone formation and tumori- 
genesis. Cell Death Dis 2013; 4: e463. https://doi.org/10.1038/ cddis.2012.217

[8] PENNOCK S, WANG Z. A tale of two Cbls: interplay of c-Cbl and Cbl-b in epidermal growth factor receptor downregulation. Mol Cell Biol 2008; 28: 3020-3037. https://doi. org/10.1128/MCB.01809-07

[9] JOAZEIRO CA, WING SS, HUANG H, LEVERSON JD, HUNTER $\mathrm{T}$ et al. The tyrosine kinase negative regulator c-Cbl as a RING-type, E2-dependent ubiquitin-protein ligase. Science 1999; 286: 309-312. https://doi.org/10.1126/ science.286.5438.309

[10] SHTIEGMAN K, KOCHUPURAKKAL BS, ZWANG Y, PINES G, STARR A et al. Defective ubiquitinylation of EGFR mutants of lung cancer confers prolonged signaling. Oncogene 2007; 26: 6968-6978. https://doi.org/10.1038/sj.onc.1210503

[11] ZHANG Y, QU X, HU X, YANG X, HOU K et al. Reversal of P-glycoprotein-mediated multi-drug resistance by the E3 ubiquitin ligase Cbl-b in human gastric adenocarcinoma cells. J Pathol 2009; 218: 248-255. https://doi.org/10.1002/path.2533

[12] QU X, LI Y, LIU J, XU L, ZHANG Y et al. Cbl-b promotes chemotherapy-induced apoptosis in rat basophilic leukemia cells by suppressing PI3K/Akt activation and enhancing MEK/ ERK activation. Mol Cell Biochem 2010; 340: 107-114. https:// doi.org/10.1007/s11010-010-0407-8

[13] QU X, ZHANG Y, LI Y, HU X, XU Y et al. Ubiquitin ligase Cbl$\mathrm{b}$ sensitizes leukemia and gastric cancer cells to anthracyclines by activating the mitochondrial pathway and modulating Akt and ERK survival signals. FEBS Lett 2009; 583: 2255-2262. https://doi.org/10.1016/j.febslet.2009.05.054

[14] XU L, ZHANG Y, LIU J, QU J, HU X et al. TRAIL-activated EGFR by Cbl-b-regulated EGFR redistribution in lipid rafts antagonises TRAIL-induced apoptosis in gastric cancer cells. Eur J Cancer 2012; 48: 3288-3299. https://doi.org/10.1016/j. ejca.2012.03.005

[15] VENNIN C, SPRUYT N, DAHMANI F, JULIEN S, BERTUCCI $F$ et al. H19 non coding RNA-derived miR-675 enhances tumorigenesis and metastasis of breast cancer cells by downregulating c-Cbl and Cbl-b. Oncotarget 2015; 6: 29209-29223. https://doi.org/10.18632/oncotarget.4976

[16] SHEN K, CUI D, SUN L, LU Y, HAN M et al. Inhibition of IGF-IR increases chemosensitivity in human colorectal cancer cells through MRP-2 promoter suppression. J Cell Biochem 2012; 113: 2086-2097. https://doi.org/10.1002/jcb.24080

[17] SEHAT B, ANDERSSON S, GIRNITA L, LARSSON O. Identification of $\mathrm{c}-\mathrm{Cbl}$ as a new ligase for insulin-like growth
factor-I receptor with distinct roles from Mdm2 in receptor ubiquitination and endocytosis. Cancer Res 2008; 68: 5669-5677. https://doi.org/10.1158/0008-5472.CAN-07-6364

[18] LI H, XU L, LI C, ZHAO L, MA Y et al. Ubiquitin ligase Cbl-b represses IGF-I-induced epithelial mesenchymal transition via ZEB2 and microRNA-200c regulation in gastric cancer cells. Mol Cancer 2014; 13: 136. https://doi.org/10.1186/1476-4598$\underline{13-136}$

[19] ZHANG Y, QU X, TENG Y, LI Z, XU L et al. Cbl-b inhibits $\mathrm{P}$-gp transporter function by preventing its translocation into caveolae in multiple drug-resistant gastric and breast cancers. Oncotarget 2015; 6: 6737-6748. https://doi.org/10.18632/ oncotarget. 3253

[20] CHEN J, HOU R, ZHANG X, YE Y, WANG Y et al. Calycosin suppresses breast cancer cell growth via ER $\beta$-dependent regulation of IGF-1R, p38 MAPK and PI3K/Akt pathways. PLoS One 2014; 9: e91245. https://doi.org/10.1371/journal. pone.0091245

[21] TRUITT L, FREYWALD T, DECOTEAU J, SHARFE N, FREYWALD A. The EphB6 receptor cooperates with c-Cbl to regulate the behavior of breast cancer cells. Cancer Res 2010; 70: 1141-1153. https://doi.org/10.1158/0008-5472.CAN-09-1710

[22] LO FY, TAN YH, CHENG HC, SALGIA R, WANG YC. An E3 ubiquitin ligase: c-Cbl: a new therapeutic target of lung cancer. Cancer 2011; 117: 5344-5350. https://doi.org/10.1002/ cncr.26153

[23] KNIGHT JF, SHEPHERD CJ, RIZZO S, BREWER D, JHAVAR $S$ et al. TEAD1 and c-Cbl are novel prostate basal cell markers that correlate with poor clinical outcome in prostate cancer. Br J Cancer 2008; 99: 1849-1858. https://doi.org/10.1038/ sj.bjc. 6604774

[24] KLAMPFL T, MILOSEVIC JD, PUDA A, SCHÖNEGGER A, BAGIENSKI $\mathrm{K}$ et al. Complex patterns of chromosome 11 aberrations in myeloid malignancies target CBL, MLL, DDB1 and LMO2. PLoS One 2013; 8: e77819. https://doi. org/10.1371/journal.pone.0077819

[25] DAS F, DEY N, BERA A, KASINATH BS, GHOSH-CHOUDHURY $\mathrm{N}$ et al. MicroRNA-214 Reduces Insulin-like Growth Factor-1 (IGF-1) Receptor Expression and Downstream mTORC1 Signaling in Renal Carcinoma Cells. J Biol Chem 2016; 291: 14662-14676. https://doi.org/10.1074/jbc.M115.694331

[26] CHEN G, FANG T, HUANG Z, QI Y, DU S et al. MicroRNA133a Inhibits Osteosarcoma Cells Proliferation and Invasion via Targeting IGF-1R. Cell Physiol Biochem 2016; 38: 598-608. https://doi.org/10.1159/000438653 